\title{
Bio-Oil Characterizations of Spirulina platensis Residue (SPR) Pyrolysis Products for Renewable Energy Development
}

\section{SITI Jamilatun ${ }^{1, a}$, ASTER Rahayu ${ }^{1, b}$, YANO Surya Pradana ${ }^{2, c}$, BUDHIJANTO ${ }^{2, \mathrm{~d}}, \mathrm{ROCHMADI}^{2, \mathrm{e}}$ and ARIEF Budiman ${ }^{2,3, f^{*}}$}

\author{
${ }^{1}$ Department of Chemical Engineering, Faculty of Industrial Technology, Universitas Ahmad \\ Dahlan, Jalan Kapas 9, Yogyakarta 55166, Indonesia Indonesia
}

\begin{abstract}
${ }^{2}$ Department of Chemical Engineering, Faculty of Engineering, Universitas Gadjah Mada, Jalan Grafika 2, Yogyakarta 55284,

${ }^{3}$ Center for Energy Studies, Universitas Gadjah Mada, Sekip K1A, Yogyakarta 55284, Indonesia

asitijamilatun@che.uad.ac.id, baster.rahayu@che.uad.ac.id, cyanopradana@ugm.ac.id, dbudhijanto@ugm.ac.id, 'rochmadi@ugm.ac.id, fabudiman@ugm.ac.id
\end{abstract}

${ }^{*}$ Corresponding author: phone/fax: +62 274902170

\begin{abstract}
Keywords: Spirulina platensis Residue, Oxygenate, Aliphatic, Aromatic.
\end{abstract}
\begin{abstract}
Nowadays, energy consumption has increased as a population increases with socioeconomic developments and improved living standards. Therefore, it is necessary to find a replacement for fossil energy with renewable energy sources, and the potential to develop is biofuels. Bio-oil, water phase, gas, and char products will be produced by utilizing Spirulina platensis (SPR) microalgae extraction residue as pyrolysis raw material. The purpose of this study is to characterize pyrolysis products and bio-oil analysis with GC-MS. Quality fuel is good if O/C is low, $\mathrm{H} / \mathrm{C}$ is high, $\mathrm{HHV}$ is high, and oxygenate compounds are low, but aliphatic and aromatic are high. Pyrolysis was carried out at a temperature of $300-600^{\circ} \mathrm{C}$ with a feed of 50 grams in atmospheric conditions with a heating rate of $5-35^{\circ} \mathrm{C} / \mathrm{min}$, the equipment used was a fixed-bed reactor. The higher the pyrolysis temperature, the higher the bio-oil yield will be to an optimum temperature, then lower. The optimum temperature of pyrolysis is $550^{\circ} \mathrm{C}$ with a bio-oil yield of $23.99 \mathrm{wt} \%$. The higher the pyrolysis temperature, the higher the $\mathrm{H} / \mathrm{C}$, the lower $\mathrm{O} / \mathrm{C}$. The optimum condition was reached at a temperature of $500^{\circ} \mathrm{C}$ with the values of $\mathrm{H} / \mathrm{C}$, and $\mathrm{O} / \mathrm{C}$ is 1.17 and 0.47 . With an increase in temperature of $300-600^{\circ} \mathrm{C}$, HHV increased from $11.64 \mathrm{MJ} / \mathrm{kg}$ to $20.63 \mathrm{MJ} / \mathrm{kg}$, the oxygenate compound decreased from 85.26 to $37.55 \mathrm{wt} \%$. Aliphatics and aromatics increased, respectively, from 5.76 to $36.72 \mathrm{wt} \%$ and 1.67 to $6.67 \mathrm{wt} \%$.
\end{abstract}

\section{Introduction}

Renewable energy sustainable with the production of heat and power available throughout the world can be obtained from biomass sources, one of which comes from microalgae. Microalgae development has many advantages over energy sources from other biomass, such as high biomass production rates, no competition with food, and no need for extensive land for growth $[1,2]$.

Biodiesel production from microalgae by extraction produces solid residues to be reused as a source of raw materials to produce biofuels [3]. Esterification of microalgae Spirulina platensis produces solid residues that can be called Spirulina platensis residue (SPR). The advantage is that they still contain a lot of carbohydrates and high protein [4]. SPR processing by fermentation will produce ethanol, while processing by pyrolysis will produce biofuels (char, biogas, and bio-oil). The use of microalgae with low lipid content such as Spirulina platensis (4-9\% lipid) as pyrolysis feedstock is very beneficial because it can optimize the yield of bio-oil products by almost $40 \%$ $[5,6]$.

Biomass pyrolysis generally involves two main steps: primary and secondary pyrolysis [7]. The main products of pyrolysis are non-condensable gases (for example, $\mathrm{CO}, \mathrm{CO}_{2}$, and $\mathrm{H}_{2}$ ), light hydrocarbons (for example, $\mathrm{CH}_{4}, \mathrm{C}_{2} \mathrm{H}_{4}$ ), condensable gases (bio-oil and water phase), solid residues (char), and mineral ash. 
If the primary pyrolysis product undergoes further reactions at higher temperatures and longer residence time, secondary pyrolysis will occur [8].

Bio-oil is a liquid fuel made from biomass such as urban waste agriculture, agricultural, and forestry byproducts through biochemical or thermochemical processes [9], consisting of carbon, hydrogen, and oxygen elements with little nitrogen and sulfur content. The largest organic components in bio-oil are lignin, alcohol, organic acids, and carbonyl. Bio-oil has a greater heating value than other liquid fuels containing oxygen (such as methanol), and its value is only slightly lower than that of diesel and other light fuel oil [10,11]. Bio-oil from microalgae has a higher heating value compared to biomass. Bio-oil from microalgae has better quality than other biomass and can produce energy of $39.7 \mathrm{MJ} / \mathrm{kg}$. The development of bio-oil can be a substitute for hydrocarbon fuels in the industry and effectively used as a substitute for diesel, heavy fuel oil, light fuel oil, and can be used in various types of boilers [12-15].

From the explanation above, the opportunity to utilize solid residues from the extraction of microalgae for fuel production by pyrolysis is very promising when considering the calorific value and composition of the bio-oil of the product. Identification of the composition of bio-oil compounds at various pyrolysis temperatures is important so that efforts are made to upgrade biooil to be applied in the industry. In this research, the characterization of Spirulina platensis residue (SPR) microalgae pyrolysis products for the development of renewable energy will be conducted.

\section{Material and Method}

Material: Spirulina platensis residue (SPR). The byproduct of Spirulina platensis extraction is a solid residue dried first and called Spirulina platensis residue (SPR). Before used for the pyrolysis of SPR samples, ultimate, proximate, and HHV were analyzed. Proximate and HHV analysis was carried out at Laboratorium Pangan dan Hasil Pertanian, Departemen Teknologi Pertanian, and Laboratorium Pangan dan Gizi from Pusat Antar Universitas (PAU), UGM. As for the ultimate (C, $\mathrm{H}, \mathrm{O}, \mathrm{N}$, and S), it was conducted at Laboratorium Pengujian, Puslitbang Tekmira, Bandung.

Method: SPR microalgae pyrolysis experiments were carried out with fixed-bed reactors made of stainless steel with dimensions: inner diameter $=40 \mathrm{~mm}$, outer diameter $=44 \mathrm{~mm}$, and height $=$ $600 \mathrm{~mm}$. The SPR pyrolysis apparatus consisted of three (3) parts: a reactor equipped with a heater, condenser, and gas reservoir [3].

\section{Research Methods}

Fifty (50) gram of SPRs were put into the reactor, tightly closed and heated. The reactor was heated externally by an electric furnace, and the temperature was controlled by a $\mathrm{NiCr}-\mathrm{Ni}$ thermocouple placed outside the furnace. The samples tested were heated at a heating rate of 5$35^{\circ} \mathrm{C} / \mathrm{min}$ from room temperature to $300^{\circ} \mathrm{C}$, then kept constant for 1 hour. The gas formed was condensed, the condenser came out, and the condenser was collected in an accumulator. Then, the amount of non-condensable gas product was measured. The experiments were repeated in the same way for temperatures of $400,500,550$, and $600^{\circ} \mathrm{C}$.

Liquid products in the form of a mixture of bio-oil and the water phase were separated by decantation. After the experiment was finished, the number of solids (char) left behind was taken and weighed. The total liquid products (bio-oil and water phase), char, and gas are calculated by the equation [14]:

$$
\begin{aligned}
& Y_{L}=\left(W_{L} / W_{M}\right) \times 100 \% \\
& Y_{B 0}=\left(W_{B 0} / W_{M}\right) \times 100 \% \\
& Y_{A}=\left(W_{A} / W_{M}\right) \times 100 \%=Y_{L}-Y_{B 0} \\
& Y_{C}=\left(W_{C} / W_{M}\right) \times 100 \% \\
& Y_{G}=1-\left(Y_{L}+Y_{C}\right)
\end{aligned}
$$


In this case, the $Y_{L}, Y_{A}, Y_{B o}, Y_{C}$, and $Y_{G}$ notations are liquid product yields; water phase, bio-oil, char, and gas. Meanwhile, $W_{M}, W_{L}, W_{A}, W_{B o}$, and $W_{C}$ are respectively the initial SPR weight, the weight of the liquid product, the water phase, bio-oil, and char.

\section{Results and Discussion}

\section{Characteristics of Spirulina platensis residue (SPR)}

To discover the characteristics of the composition of Spirulina platensis residue (SPR), proximate and ultimate analysis and heat value (HHV) were carried out. The analytical results were for components $\mathrm{C}(41.36 \mathrm{wt} \%), \mathrm{H}(6.60 \mathrm{wt} \%)$, and $\mathrm{N}(7.17 \mathrm{wt} \%), \mathrm{O}(35.33 \mathrm{wt} \%)$. Meanwhile, for the proximate analysis, the lipids at SPR $(0.09 \mathrm{wt} \%)$ were very low, and HHV $(18.21 \mathrm{MJ} / \mathrm{kg})$ [3-5].

\section{Product yield}

The yield of the SPR pyrolysis product was calculated by equation (1-5). SPR pyrolysis experiment was carried out three (3) times, product yield was the average value, and the results are shown in Fig. 1.
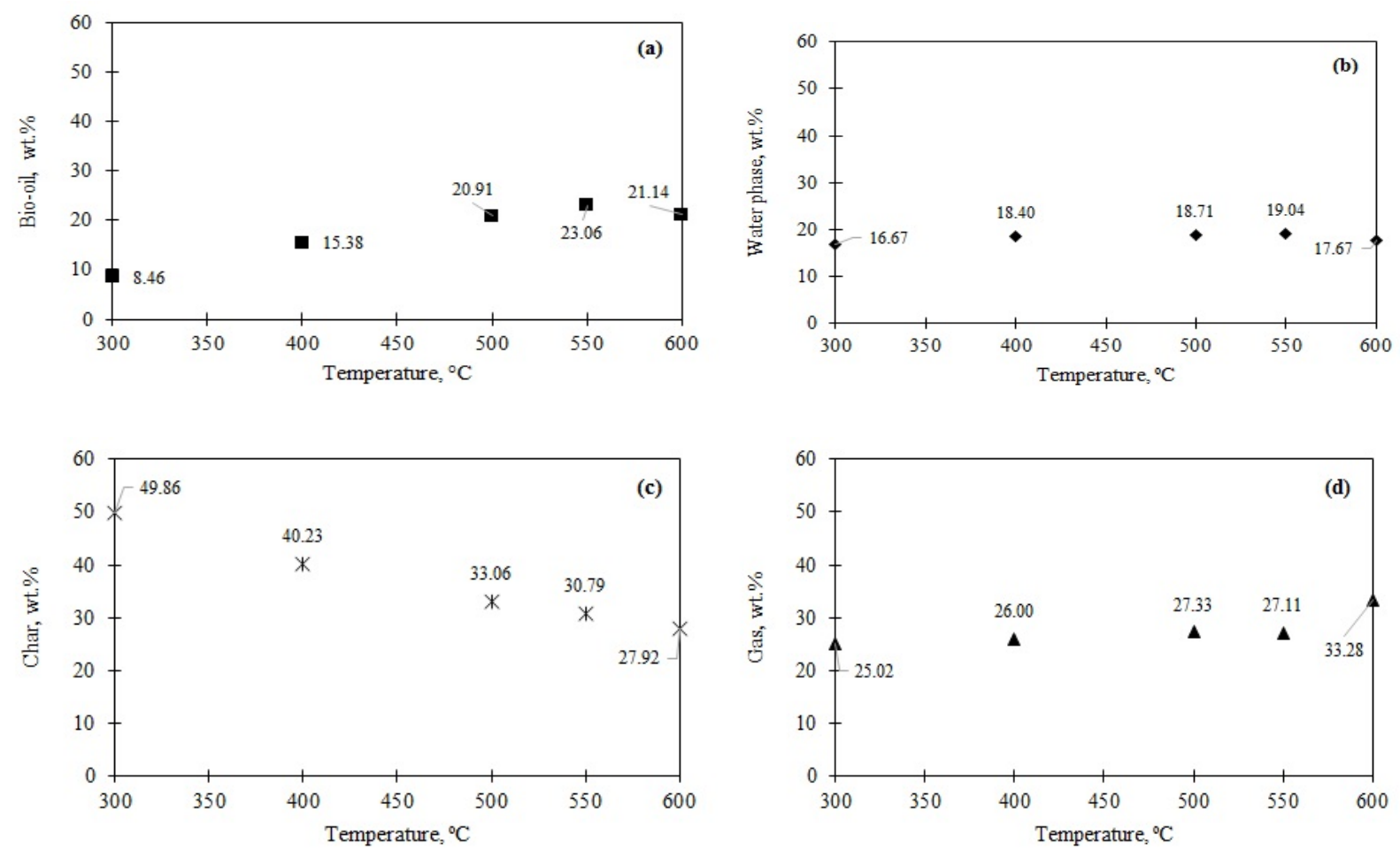

Fig. 1. Relationship between the effect of temperature on product yield: (a) bio-oil, (b) water phase, (c) char, and (d) gas

From Fig. 1, we can see the effect of temperature on the yield of bio-oil, water phase, char, and gas with a heating rate of $5-35^{\circ} \mathrm{C} / \mathrm{min}$. From Fig. 1(a), the lowest bio-oil yield $(8.46 \mathrm{wt} \%)$ occurs at $300^{\circ} \mathrm{C}$ but will rise sharply to $550^{\circ} \mathrm{C}(23.06 \mathrm{wt} \%)$ and then drops again at $600^{\circ} \mathrm{C}(21.14 \mathrm{wt} \%)$. Meanwhile, in Fig. 1(b), the water phase from a temperature of 300 to $600^{\circ} \mathrm{C}$ rises slightly, then falls with the amount in the range of 16.17 to $19.04 \mathrm{wt} \%$. As for Fig. 1(d), the char yield at 300$600^{\circ} \mathrm{C}$ falls sharply from 49.86 to $27.92 \mathrm{wt} \%$. The yield of bio-oil and water phase above the optimum temperature of $550{ }^{\circ} \mathrm{C}$ will decrease due to secondary cracking (cracking, polymerization, condensation) reaction, because the liquid product in primary cracking will partially decompose into gas so that the yield of bio-oil and the water phase will go down. The yield water phase has increased because of temperature rise from $300-400^{\circ} \mathrm{C}$, then it is relatively stable at $400-550{ }^{\circ} \mathrm{C}$ and drops slightly above $550^{\circ} \mathrm{C}$. Yield from the water phase is influenced by the water content in the SPR (9.99 wt \% free water) and the reactions of water formation during pyrolysis (dehydration). 
From Fig. 1(c), gas yields increase relatively as temperature increases from $300-550^{\circ} \mathrm{C}(25.52-$ $27.11 \%$ ), above $550^{\circ} \mathrm{C}$ the increase in gas yield is relatively sharpie from 27.11 to $33.28 \%$. The addition of this gas is due to secondary cracking (cracking, polymerization, condensation) products in tar, which produce a gas called secondary gas. The total amount of non-condensable gas is the sum of gas produced from primary and secondary reactions, namely primary and secondary gases $[5,6]$.

\section{Characteristics of Bio-oil}

Effect of temperature on $\mathbf{O} / \mathbf{C}, \mathbf{H} / \mathbf{C}$, and HHV: The effect of temperature on $\mathrm{H} / \mathrm{C}$ and $\mathrm{O} / \mathrm{C}$ is presented in Fig. 2(a), while the effect of temperature on HHV can be seen in Fig. 2(b). From Fig. 2(a), it can be seen that $\mathrm{O} / \mathrm{C}$ and $\mathrm{H} / \mathrm{C}$ bio-oil from temperatures of $300-600^{\circ} \mathrm{C}$ in the range $0.33-0.78$ and $0.64-1.25$. $\mathrm{O} / \mathrm{C}$ range value in bio-oil is lower than $\mathrm{SPR}$ of 0.85 , while the amount of $\mathrm{H} / \mathrm{C}$ range of bio-oil is higher than SPR, which is 0.16 . This indicates that with SPR pyrolysis, a better quality bio-oil is produced, the higher the temperature, the lower $\mathrm{O} / \mathrm{C}$, the higher $\mathrm{H} / \mathrm{C}$. The optimum conditions are reached at $500^{\circ} \mathrm{C}$, i.e., $\mathrm{O} / \mathrm{C}$ and $\mathrm{H} / \mathrm{C}$ values are respectively 0.33 and 1.25 . From Fig. 2(b), it can be seen that the rise in temperature causes the HHV to rise to an optimum temperature, ie, at $600^{\circ} \mathrm{C} \mathrm{HHV}$ value is $20.71 \mathrm{MJ} / \mathrm{kg}$.
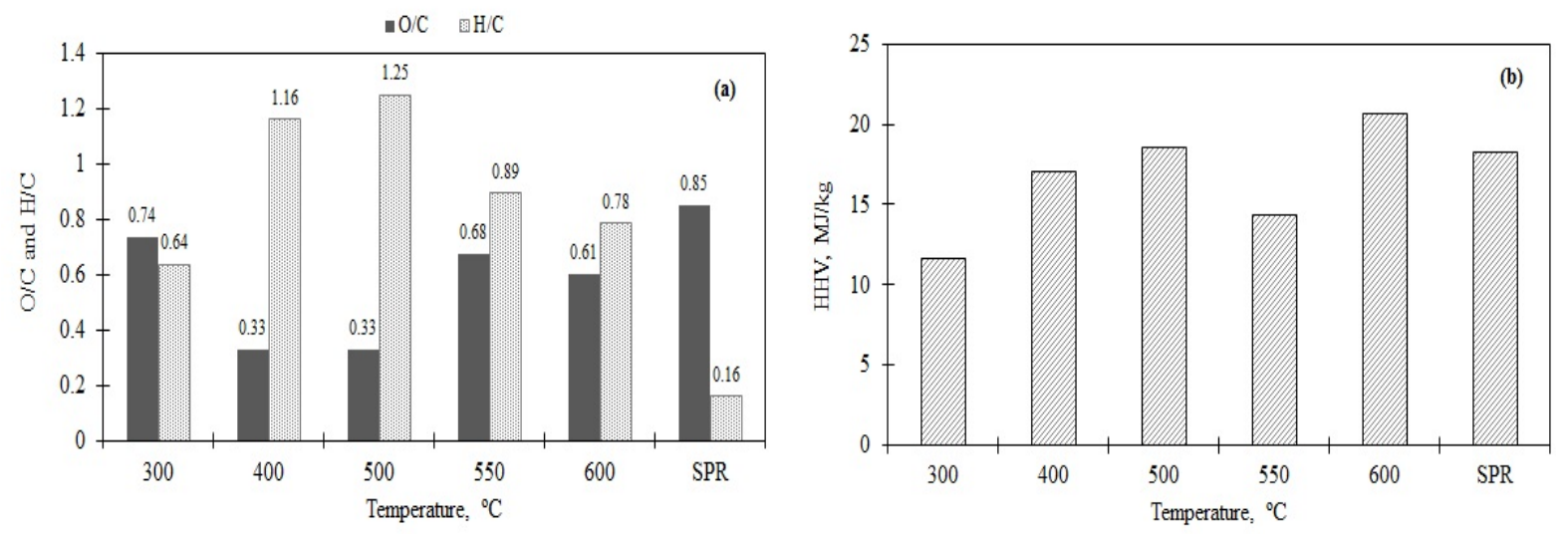

Fig. 2. Effect of temperature on (a) $\mathrm{O} / \mathrm{C}$ and $\mathrm{H} / \mathrm{C}$ ratio of bio-oil, (b) $\mathrm{HHV}$

Effect of temperature on four (4) bio-oil functional groups. From the research results, bio-oil products are analyzed by GC-MS and obtained more than 100 kinds of components, but can be categorized into 4 functional groups namely oxygenate compounds (ether, ester, alcohol, acid, aldehyde, ketone and phenol), nitrogenate, aliphatic, and aromatics (mono aromatic and polyaromatic) which are presented in Fig. 3.

The oxygenate compound (Fig. 3(a)) decreases (85.26-37.55 wt\%) with an increase in temperature $\left(300-600^{\circ} \mathrm{C}\right)$. This can be explained by the rise in temperature, cracking of oxygenate compounds (phenol, ketone, aldehydes, acids, and alcohols) faster, so that oxygenate compounds are cut into aliphatic and aromatic by releasing $\mathrm{CO}, \mathrm{CO}_{2}$ gas, etc. The nitrogenate compound (Fig. $3(b)$ ) is produced from cracking protein, the increase in the number of nitrogenate compounds (7.32-20.93 wt.wt\%) is caused by the deamination reaction, and Maillard's reaction with carbohydrates produces Amadori compounds [2].

From Fig. 3 (c), it can be explained that on the aliphatic compound, the higher the pyrolysis temperature $\left(300-600^{\circ} \mathrm{C}\right)$, the higher it is (5.76-39.02 wt \%). Aliphatic compounds (alkanes and alkenes) are formed by a series of reactions from carbohydrates. The first step is (i) the hydrolysis and cracking reactions produce anhydrosugars and furfurals, (ii) the decarboxylation and deoxygenation reactions produce ketones, aldehydes, acids, and alcohols. The second step is continued by cracking to form olefin. Aliphatic can also be produced from protein by cracking, followed by deoxygenation (2). The higher the pyrolysis temperature, the faster the decomposition, the more aliphatic formation produces $\mathrm{NH}_{3}$ and long-chain olefins [16]. A non-significant aromatic increase (Fig. 3(d)) indicates that the cyclization of olefins is less effective even though the pyrolysis temperature is raised [16]. 
Decomposition will also produce lighter hydrocarbon compounds, methane, hydrogen, $\mathrm{CO}_{2}$, and $\mathrm{CO}$, indicated by an increase in gas yield. This happens because, at high temperatures, the acid group instability occurs so that the oxygenate function group decomposes to form $\mathrm{CO}$ and $\mathrm{CO}_{2}$. The decrease in oxygenating compounds indicates that the quality of bio-oil is getting better with an increase in pyrolysis temperature, which is optimum at $600^{\circ} \mathrm{C}(37.55 \mathrm{wt} \%)$.
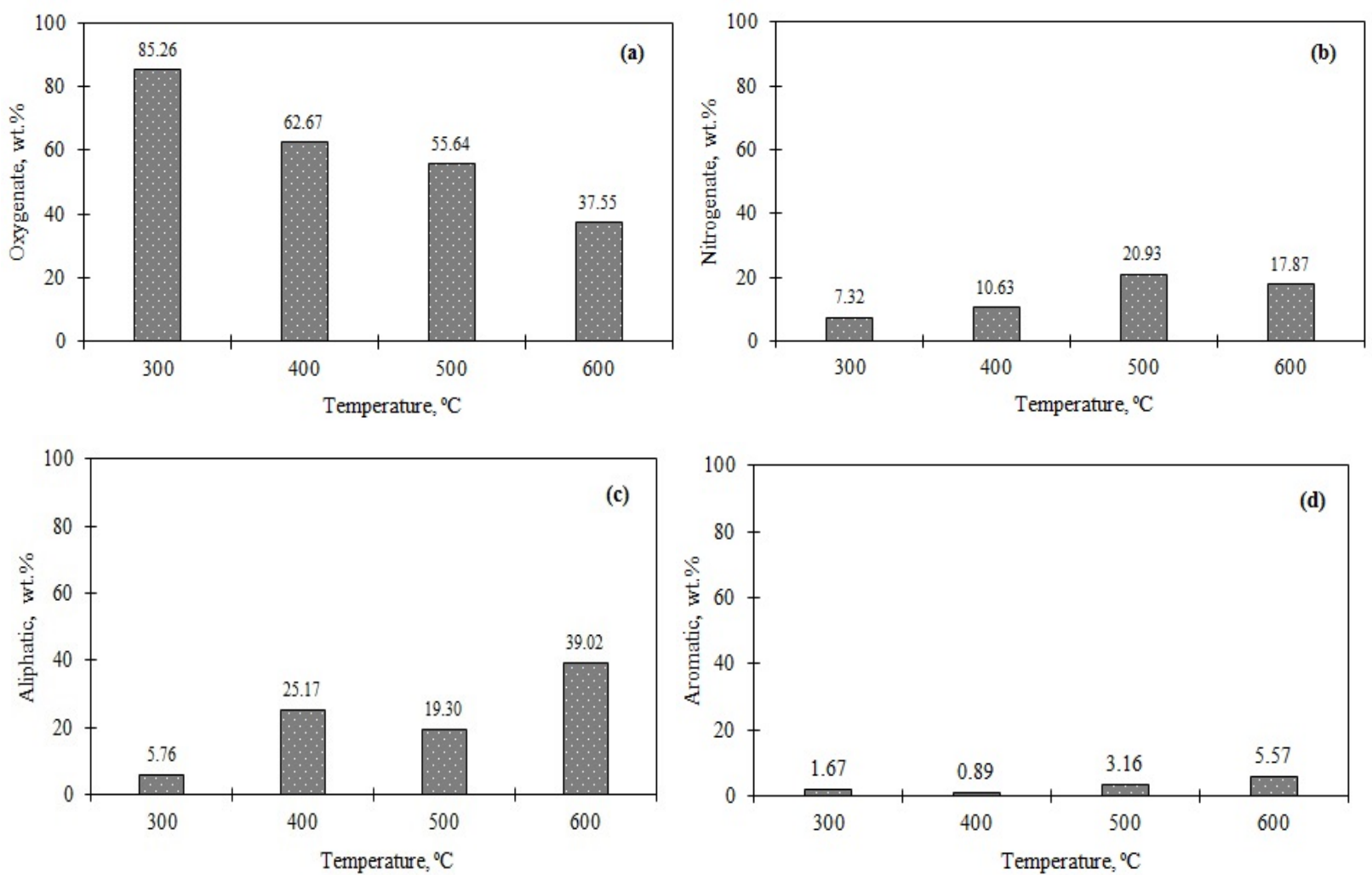

Fig. 3. Effect of temperature on the functional groups making up bio-oil: (a) oxygenate, (b) nitrogenate, (c) aliphatic and (d) aromatic

\section{Conclusion}

The oxygenate and $\mathrm{O} / \mathrm{C}$ compounds are quite low, and $\mathrm{HHV}$ is quite high, so bio-oil has the potential as a profitable new renewable energy (EBT) fuel. In pyrolysis without catalyst, the higher the pyrolysis temperature, the lower the bio-oil yield will be to an optimum temperature, then decrease. The optimum pyrolysis temperature is $550^{\circ} \mathrm{C}(23.99 \mathrm{wt} \%$ bio-oil $)$ and at $600^{\circ} \mathrm{C}$ (33.28 $\mathrm{wt} \%$ gas). The higher the pyrolysis temperature, the higher the $\mathrm{H} / \mathrm{C}$, the lower $\mathrm{O} / \mathrm{C}$. The optimum conditions are reached at a temperature of $500^{\circ} \mathrm{C}$, the values of $\mathrm{H} / \mathrm{C}$ and $\mathrm{O} / \mathrm{C}$ are 1.17 and 0.47 . HHV increases from $11.64 \mathrm{MJ} / \mathrm{kg}$ to $20.63 \mathrm{MJ} / \mathrm{kg}$, with an increase in temperature from 300 to $600^{\circ} \mathrm{C}$. Oxygenate compounds decrease with an increase in temperature, ie, from an average of $85.26\left(300^{\circ} \mathrm{C}\right)$ to $37.55 \mathrm{wt} \%\left(600^{\circ} \mathrm{C}\right)$, a decrease in oxygenating compounds is around $55.96 \%$. Aliphatics and aromatics increase from $300-600^{\circ} \mathrm{C}$, respectively, from 5.76 to $36.72 \mathrm{wt} \%$ and 1.67 to $6.67 \mathrm{wt} \%$.

\section{Acknowledgment}

The authors are very grateful to the Ministry of Research, Technology, and Higher Education, the Republic of Indonesia, for financial support. 


\section{References}

[1] H. Anggorowati, S. Jamilatun, B. Rochim, Cahyono, and A. Budiman, Effect of Hydrochloric Acid Concentration on the Conversion of Sugarcane Bagasse to Levulinic Acid. IOP Conf. Ser.: Mater. Sci. Eng. 299 (2018), 012092.

[2] C. Yang, R. Li, B. Zhang, Q. Qiud, B. Wang, H. Yang, Y. Ding and C. Wang, Pyrolysis of microalgae: A critical review, Fuel Processing Technology, 186 (2019), 53-72.

[3] S. Jamilatun, Budhijanto, Rochmadi and A. Budiman, Non-catalytic slow pyrolysis of Spirulina platensis residue for production of liquid biofuel. Int. J. Renew. Energy Res. 7(4) (2017), 1901-1908.

[4] S. Jamilatun, Budhijanto, Rochmadi, A. Yuliestyan and A. Budiman, Effect of grain size, temperature, and amount of catalyst on characteristics of pyrolysis products from Spirulina platensis residue (SPR), International Journal of Technology 10(3) (2019), 541-550.

[5] S. Jamilatun, Budhijanto, Rochmadi, A. Yuliestyan and A. Budiman, Valuable Chemicals Derived from Pyrolysis Liquid Products of Spirulina platensis Residue, Indones. J. Chem., 19 (3) (2019), $703-711$.

[6] K. Chaiwong, T. Kiatsiriroat, N. Vorayos and C. Thararax, Study of bio-oil and bio-char production from algae by slow pyrolysis, Biomass Bioenergy, 56 (2013, 600-606.

[7] $\mathrm{X}$. Hu and M. Gholizadeh, Biomass pyrolysis: A review of the process development and challenges from initial researches up to the commercialisation stage, Journal of Energy Chemistry, 39 (2019), 109-143.

[8] P. Basu, Biomass gasification and pyrolysis. Practical design and theory. Elsevier Inc. (2010).

[9] S. Wang, G. Dai, H. Yang and Z. Luo, Lignocellulosic biomass pyrolysis mechanism: A state-of-the-art review, Progress in Energy and Combustion Science, 62 (2017), 33-86.

[10] G.W. Huber, S. Iborra and A. Corma, Synthesis of transportation fuels from biomass: chemistry, catalysts, and engineering. Chem. Rev. 106 (2006), 4044-4098.

[11] Z. Hu, Y. Zheng, F. Yan, B. Xiao, and S. Liu, Bio-oil production through pyrolysis of bluegreen algae blooms (BGAB): Product distribution and bio-oil characterization, Energy, 52 (2013), 119-125.

[12] Z. Du, B. Hu, X. Ma, Y. Cheng, Y. Liu and X. Lin X, Catalytic pyrolysis of microalgae and their three major components: carbohydrates, proteins, and lipids. Bioresour. Technol, 130 (2013), 777-82.

[13] S. Jamilatun, Budhijanto, Rochmadi, A. Yuliestyan and A. Budiman, Comparative Analysis Between Pyrolysis Products of Spirulina platensis Biomass and Its Residues, Int. J. Renew. Energy Dev., 8 (2) (2019), 113 - 140.

[14] A. Demirbas, Biodiesel production from vegetable oils via catalytic and non-catalytic supercritical methanol transesterification methods. Pror Energy Combust Sci, 31(5-6) (2003), 466-87.

[15] S. Jamilatun, Budhijanto, Rochmadi, and A. Budiman, Thermal Decomposition and Kinetic Studies of Pyrolysis of Spirulina platensis Residue. International Journal of Renewable Energy Development, 6(3) (2017), pp. 193-201.

[16] S. Jafarian, and A. Tavasoli, A comparative study on the quality of bioproducts derived from catalytic pyrolysis of green microalgae Spirulina (Arthrospira) plantensis over transition metals supported on HMS-ZSM5 composite, International Journal of Hydrogen Energy, 43 (2018), pp. 19902-19917. 